\title{
Material Development of Mutual Cooperation in Akidah Akhlak Subject (Study on Berinjam tradition in SDN Kuala Jelai)
}

\author{
Alimaturraiyah
}

Institut Agama Islam Negeri Pontianak

alimaturraiyah221995@gmail.com

\section{Wahab}

Institut Agama Islam Negeri Pontianak

\begin{abstract}
This study discusses the development of Berinjam material in Akidah Akhlak subject. It is expected that the importance of mutual cooperation material in Akidah Akhlak subject drives students to apply commendable behavior in their daily lives both to themselves and to others. The purpose of this study is to develop teaching materials in the form of lesson plans on the basis of local wisdom. This study used a qualitative method by explaining the development of mutual cooperation material in Akidah Akhlak subject. Based on the findings, Berinjam is a form of sense of helping each other and the community performs its duties properly in accordance with habits and traditions and is carried out jointly. Material development must also refer to the 2013 curriculum. In the matter of mutual cooperation, SD / MI is contained in aspects of morality. The material from Berinjam is intended to make everyone becomes educated in the sense of thinking, listening and be righteous. Berinjam material which is contextualized in mutual cooperation material seizes to shape smart and educated students. In addition, efforts to bring students closer to the peculiarities of the local culture in their homes will not work well if teachers cannot convey it properly. Therefore, teachers must have an adequate understanding of the local cultural values, in addition to their ability to develop the subject matter must be accompanied by contextual so that learning can be achieved. Thus, Berinjam material must be developed through internalization by helping, cooperating and respecting each other.
\end{abstract}

Keywords: Development, Material, Berinjam, Akidah Akhlak Subject. 


\section{INTRODUCTION}

Education is basically related to the transformation of science as well as schools that are formal institutions are the basis of education. Education in schools is part of the national education system which has a very important role in improving human resources. Through education in schools it is expected to produce qualified human resources.

The overall success of learning depends on the success of teachers in designing learning material. In local wisdom-based education, guidelines for local wisdom values are the criteria that determine the quality of students. As a decisive criterion, the values of local wisdom can be the basis for developing more characteristic learning (Nadlir, 2014: 309). The purpose of local wisdom-based education in accordance with article that has been embodied in national law, namely law number 20 of 2003 concerning the national education system in article 3 states that national education functions to develop capabilities and shape the dignity of the nation's character and civilization in order to educate the nation's life (Dorector General, 2007: 54).

The development of teaching materials is used as a way of identifying, developing and learning strategies. The development of fun teaching materials and instilling moral values for students is very necessary. This is to improve the quality of students in the realm of knowledge, skills and attitudes as the core of the 2013 curriculum. The 2013 text-based curriculum is used as an educator to develop and compile quality, varied teaching materials and maintain basic aspects in the 2013 curriculum. 
What has been faced by teachers in the current learning activities is to choose teaching materials and learning materials that are appropriate in order to help students to achieve competence. This is due to the fact that in achieving competence, curriculum and teaching materials are only written in broad outline in the form of subject matter.

Teachers' task is to describe the subject matter so that it becomes a complete teaching material. Learning in educational institutions consists of various teaching materials, in which each of the learning objectives has been determined. Without invading any teaching material at all, the content of local wisdom needs to be included. So that any material received by students is a form of teaching material, both in the form of theory, practice and attitudes of the educators themselves. This also applies in developing learning material based on local wisdom and the role of teachers is very important because teachers are role model that will provide good example to students and the surrounding environment (Zulkifli, 2017: 131).

Local wisdom as a knowledge found by certain local communities through a collection of experiences in trying and being integrated with culture and natural understanding in certain place (Padmanugraha, 2010: 12). The form of local wisdom will be more easily identified through the educational process about daily life developed by school institutions both from the style, process and method. Local cultural values need to be developed and become material for Islamic education that is inserted in a position equal to the values of local wisdom. As consideration, to integrate 
character values in education, schools become the main space for character formation of students. Therefore, schools must develop a culture of character education in the learning process as a school culture (Hasby Ali, 2017: 529).

If the values of local wisdom are not maintained, it is feared that it will gradually experience the process of extinction. One effort to maintain is by using local culture in the learning process at school. Because culture is one of the characteristics of the region itself (Mawardi Rival, 2000: 11) in (Wahab, 2015: 254).

As written by Nasir \& Hand (2006: 449) that "research on race, culture, and schooling has revealed many significant factors affecting school achievement and has intersected many details of culture and learning intersect in daily school life". The orientation of education that overemphasizes the cognitive aspects and ignores other aspects of personality that are more important must be changed immediately.

Education milieu needs to be spurred as well planned and directed to create conscious, educated, and qualified human being (Tilaar, 2002: 98). The meaning of the conscious, educated and qualified relationship with mutual cooperation is the need for mutual cooperation material so it becomes developed and qualified for both teachers and students on the basis of local wisdom. So from this pattern, teachers will be a good facilitator for internalizing the values of local wisdom to students in the learning process. Because mutual cooperation is also related to the development in learning Islamic education. The Ministry of Education 
and Culture states that there are several indicators for mutual cooperation. Namely actively involved in school work, doing tasks according to agreement, willing, active in group work, putting aside personal interests and prioritizing common interests, encouraging others to work together for the common good (2014: 70).

Therefore, the researchers have given several important reasons related to the development of mutual cooperation material in Akidah Akhlak subjects. The very first thing the researchers explain is the importance of mutual cooperation material in Akidah Akhlak subject because this is subject in the secondary education level that discusses the teaching of Islam in terms of faith and morality. The subject of Aqidah Akhlak is conscious and planned efforts in preparing students to identify, understand, live and believe in Allah SWT and realize it in noble moral behavior in everyday life through the formation of attitudes, attitude and moral formation,

Thus the importance of mutual cooperation akidah akhlak subject it is expected that students can apply this commendable behavior in their daily lives both to themselves and to others. Moreover, the importance of mutual cooperation for elementary school children is to instill mutual cooperation values by implementing cleaning activities in schools. Before carrying out these cleaning activities, teachers teach students how important it is to maintain cleanliness in daily life.

By applying this, teachers have instilled the values of mutual cooperation in the children. Furthermore, why the mutual assistance 
material needs to be developed on the basis of local wisdom because by using local wisdom it teaches students to always be attached to the concrete situation they face in daily life. This local wisdom-based learning is actually a form of realization of Government Regulation Number 19 of 2005 concerning National Education Standards, article 17 paragraph 1 which explains that the elementary-high school education unit curriculum, or other equivalent forms are developed in accordance with educational units, regional potential , social culture, and students (Hadi Susanto, 2017: 45)

In fact, Berinjam is something unique because Berinjam is not only completed individually but carried out together so that local wisdom is attached to the people of Kuala Jelai. In addition, Berinjam is also not only applied in the community but also in the school environment. Teachers have taught Berinjam in local wisdom circumstances.

Other than that, Berinjam is important in the development of mutual cooperation in the Kuala Jelai community because mutual cooperation enacts people to help each other. No matter how small the contribution in mutual cooperation is, it can always provide help and benefits for others. Mutual cooperation can make people realize that they are social beings. Mutual cooperation makes people get to know each other so that the process of socialization is maintained continuously. It is appropriate for human to mutually cooperate with each other, inviting one another to do good deeds. Islam has commanded it beautifully. As Allah SWT has said: 


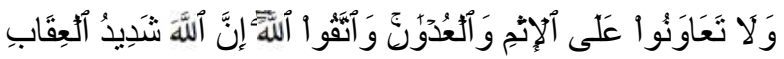

Meaning : And cooperate in righteousness and piety, but do not cooperate in sin and aggression. And fear Allah; indeed, Allah is severe in penalty. (Al Maidah: 2)

Therefore, this study aims to identify and contribute to the development of mutual cooperation material in Akidah Akhlah Subject at Kuala Jelai Elementary School in Central Kalimantan. With the contribution that the researchers, this could improve the development of mutual cooperation material in Akidah Akhlak subjects.

Several previous relevant studies (related to previous research with mutual cooperation research) as well as the development of learning materials, including: research conducted by Ana Nurhasanah (2016) with Journal entitled " Teaching material development on local cultural values (Studies in Baduy indigenous people) " The result of the study shows that the learning of local culture in the development of the material values of the traditional traditions of the Baduy indigenous people began with learning activities tailored to the learning objectives including the ability to cooperate, responsibility, finding learning resources, independency, bravery, punctuality, never give up, tolerance and connecting historical events with everyday life in an effort to prepare community who are multicultural and love and pride towards Indonesia; research conducted by Salamun (2002) with Thesis title "Community service culture of the Javanese ethnic community in Wonosobo Regency". Community service has become part of mutual cooperation activities of the Javanese 
community, especially for celebration or event for the sake of environmental cleanliness. In community service there are also snacks and drinks provided that are also procured from mutual cooperation. Community service is carried out if it is commanded or related to the needs of environmental cleaning activities. But in its implementation, it is more actualized in rural areas than in urban areas. Based on observation, social solidarity in rural and urban areas is different. This is because the communities of the two regions have different physical and social boundaries. Both communities a social relationship is formed which determines the intensity of the relationship between one citizen and another or what is called neighborhood; research conducted by Subagyo (2012) with the title "Development of values and traditions of mutual cooperation in the frame of conservation of cultural values". The study shows that the existence of a mutual cooperation tradition in Indonesian community as a legacy of the past that is transformed generationally (traditional heritage) is a local wisdom that needs to be developed in the lives of present-day generations. The value of mutual cooperation can be utilized positively in life to drive social solidarity so that the Indonesian is able to face the challenges of time, globalization, and various things that threaten people's lives such as natural disasters, social and political conflicts. Mutual cooperation becomes the institution to mobilize community solidarity and create social cohesion in the life of the Indonesia. Conservation of the value of mutual cooperation culture in the present life will remain relevant, because with the spirit of mutual 
Mudarrisa: Jurnal Kajian Pendidikan Islam, Vol. 11, No. 1, 2019

cooperation, community solidarity and national unity and integrity will be preserved.

Based on the above research, this research's similarity is to develop a local wisdom culture. But the difference lies in the focus of this research. This study focuses more on the development of mutual cooperation material on local wisdom based in akidah akhlak subjects in the Kuala Jelai elementary school.

According to Hanna P. (2014: 38) local wisdom-based development is an education effort both formal and non-formal which is carried out consciously, planned, directed, organized, and responsible in order to introduce, grow, guide, and develop a basic personality balanced, intact and harmonious, knowledge and skills in accordance with the talents, desires and abilities as a provision for the next on its own initiative to add, improve and develop themselves, others and their environment towards achieving optimal dignity, quality and human abilities and independent individuals .

According to the development of values is a criteria that must exist in an individual towards an object. But what can be done in developing value is to create a good environment (Sunarto, 2008: 120). What is meant by the development of learning is a way to identify, develop with the intention of achieving certain goals effectively and efficiently.

According to Sartini (2004: 120) how to develop local wisdom is by helping one another, working together and respecting each other. Therefore local wisdom varies in each region, because this local wisdom is 
very closely related to the management of natural resources and the environment. Efforts that can be made are through increasing the ability of the community to filter out various technologies that enter and maintain the balance of nature and the environment and adapt it to the local wisdom of the community.

The benefits of local wisdom is for the preservation of natural resources. Then local wisdom functions to develop human resources and serves as the development of culture and science (Nadlir, 2014: 312).

Local wisdom that develops in the community today is the result of the habit or culture of the local community as a form of adaptation to nature and the environment in which they live. The community uses its own ways to manage nature and the environment. These habits then form with what is called local wisdom. Local wisdom contains values, beliefs, and religious systems adopted by the local community. Local wisdom is essentially activities that protect and preserve nature and the environment. Therefore, it is important to preserve the local wisdom that develops in the community. But as time went by, the existence of local wisdom is not raised in schools anymore.

Though local wisdom will be reflected in the values that apply in certain community groups. These values become the grip of certain groups of people who will usually be an integral part of life that can be observed through their daily attitudes and behavior. Therefore researchers want to develop local wisdom-based learning which is currently still suboptimal, especially in certain schools. As well as providing solutions and images in 
developing local wisdom-based learning, so it can be applied and used by these schools. Thus, based on the above theories can be used as a reference for researchers in developing mutual cooperation material in Berinjam tradition in Akidah Akhlak subjects.

\section{METHODS}

The method used in this study is a qualitative method by describing the development of mutual cooperation material in akidah akhlak subject. The purpose of qualitative research is to describe and analyze phenomena, events, social activities, beliefs, thoughts of individuals and groups. This qualitative method is a research procedure that produces descriptive data in the form of written or oral words from people and behavior that can be observed (Sugiyono, 2017: 8).

This research used literature review, observation, interviews and documentation. Qualitative analysis was used to interpret the development of mutual cooperation material in Berinjam tradition. Thus it is also presented on the basis of the results of observations and interviews with Principals, teachers, and students in Kuala Jelai Elementary School so this research becomes more accurate and objective. In this case, the observed data sources are humans, events and circumstances (Lincoln et al., 1985: 232) in (Wahab, 2015: 254).

In this study, the characteristics that appear from the purpose of the research are obtaining an overview of the development of local wisdom-based learning in schools. Process where the researcher seeks to 
reveal a reality on the development of local wisdom-based learning in the form of descriptive data obtained from interviews, observations and documentation related to local wisdom-based learning in schools.

\section{DISCUSSION}

Based on a number of respondents who had been interviewed, Berinjam is mutual cooperation. Berinjam is a form of sense of help and people carry out their duties well according to their habits and traditions and are carried out jointly (Kusnadi, 2006: 16). As for the privilege of Berinjam is that young and old are involved in mutual cooperation, thus the work becomes easier because it is done together. In addition, the uniqueness of Barinjam is seen from the Islamic side or religious that before committing mutual cooperation it must begin with prayer. This is a tradition carried out by Muslims who are in accordance with Islamic values. The role of value in mutual cooperation is to strengthen strong solidarity, where the community believes that in every mutual cooperation or Barinjam there must be a shared value which is part of the Kuala Jelai community's solidarity.

The findings from Barinjam are very interesting and certainly must be developed through internalization by helping each other, mutual cooperation and respecting each other. Therefore local wisdom varies in each region, because this local wisdom is very closely related to the management of natural resources and the environment. The efforts that can be made are increasing the ability of the community to screen various 
technologies coming and maintaining the balance of nature and the environment and adapt it to the local wisdom of the community (Sartini, 2004: 120).

One of the importance of maintaining the value of mutual cooperation is to safeguard the traditions or habits of the people because with mutual cooperation there are many benefits that are felt widely, such as work becomes easier because of cooperation and help, strengthen relations among citizens at every event that needs mutual cooperation.

Regard to the development of material, it must refer to the 2013 curriculum. Mutual cooperation material is contained in elementary school. The material from Barinjam is intended to make everyone become educated in the sense of thinking, listening and be righteous. Berinjam material which is contextualized in mutual cooperation material will trigger students to become smarter and educated. This should be developed so Berinjam is not done textually only but also done contextually and Barinjam can be something functional in learning.

In addition, based on the findings of the researchers that the Barinjam tradition can be a development in learning Islamic religious education. Then the method and material must be interconnected so learning can be achieved effectively and efficiently. Based on 2013 syllabus and curriculum, the material for mutual cooperation is contained in the material of cooperation and helping each other.

The success in the learning process is determined by professional educators. The development of appropriate and qualified teaching 
materials is very important. When teachers deliver learning material, first to master about is how to deliver the material well so that learning material can be understood by students. According to the researchers, the elementary schools in Kuala Jelai must develop especially in mutual cooperation material, called Barinjam. Because it is the main thing in the learning context and becomes the school's commitment in order to realize character education and support the preservation of local wisdom.

One method that can be taken by teachers in schools is by internalizing the values of local wisdom in the learning process in school. By internalizing the local values in the learning process, it is expected that the locality of students will remain intact in the midst of the swift flow of globalization.

One effort to internalize the value of local wisdom is by designing, creating and developing local wisdom value-based teaching materials. The values of local wisdom in the curriculum in Kuala Jelai Elementary School are basically more focused on how to fortify students and teachers for external cultural influences. Efforts to bring students closer to the peculiarities of the local culture in their homes will not work well if the teacher is not even able to deliver it.

Therefore, teachers must have an adequate understanding of the local cultural values, in addition to their ability to develop the subject matter must be accompanied by contextual so that learning can be achieved. 
Thus, the development of material in Kuala Jelai Elementary School must be improved so that students become smarter and educated. Integration will be effective if the content of local wisdom can be inserted carefully into the main teaching material specifically to the learning of Islamic education. Schools are supposed to hold mutual cooperation activities which emphasize the introduction of local culture and the delivery media related to the social environment and cultural environment. Students are still taught to always care about the environment, especially in the school environment. It is very clear that these characters train them and familiarize themselves with instilling social values and it is important to protect the environment together. Because the character of social care is a virtue that can provide benefits, alleviate and help in social life (Rianawati, 2014: 66-67). Therefore, Allah SWT always encourages human beings to help each other. As Allah SWT says in Al-Maidah verse 2:

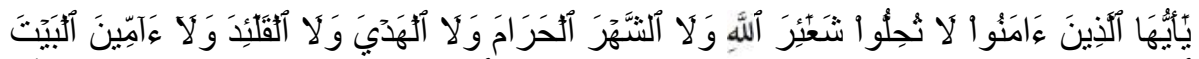

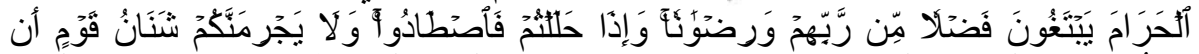

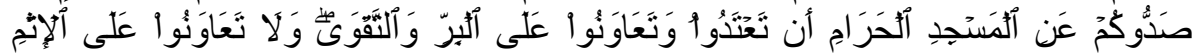

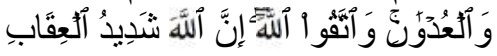

Meaning:

O you who have believed, do not violate the rights of Allah or [the sanctity of] the sacred month or [neglect the marking of] the sacrificial animals and garlanding [them] or [violate the safety of] those coming to the Sacred House seeking bounty from their Lord and [His] approval. But when you come out of ihram, then [you may] hunt. And do not let the hatred of a people for having obstructed you from al-Masjid al-Haram lead you to transgress. And cooperate in righteousness and piety, but do not cooperate in 
sin and aggression. And fear Allah; indeed, Allah is severe in penalty. (Al-Maidah: 2)

Based on the word of Allah SWT, it is very important that social values should be encouraged to students and students are expected to have an attitude of social care from an early age. This social care character can be integrated in the learning process. Furthermore, teachers are required to be more creative, especially during learning because teachers do not only deliver textually but must be accompanied by contextual or with application and examples with goal, students can apply it in their lives daily.

\section{CONCLUSION}

Based on the findings above, it can be concluded that Barinjam is a form of helping each other and the community performs its duties well in accordance with its customs and traditions and is carried out jointly. The distinction of Barinjam is that all young and old are involved in work in mutual cooperation, so that the work becomes easier. In addition, the uniqueness of Barinjam is seen from the Islamic side or religious nuance that before committing mutual cooperation it must begin with prayer.

Based on the findings, Barinjam tradition can be developed in learning Islamic education, namely in the Akidah Akhlak subjects. The findings from Barinjam are very interesting and certainly must be developed through internalization by helping, cooperating and respecting 
each other. It is expected that mutual cooperation material in akidah akhlak learning can be applied by students in commendable behavior in daily life both to themselves and to others. Based on 2013 syllabus and curriculum that the material for mutual cooperation is contained in the material of cooperation and help. In fact, Barinjam is something unique because Barinjam is not only done individually but carried out jointly so that local wisdom is well attached to the people of Kuala Jelai.

One method that can be taken by teachers in schools is by internalizing the values of local wisdom in the learning process in school. By internalizing the local values in the learning process, it is expected that the locality of students will remain intact in the midst of the swift flow of globalization. The effort to internalize the value of local wisdom is by designing, creating and developing teaching materials (Lesson Plan) based on local wisdom values. Thus in the learning context, school must commit in order to actualize character education and support the preservation of local wisdom.

\section{REFERENCES}

Ali. H. (2017). Transformasi Nilai-nilai Kearifan Lokal Dalam Proses Pembelajaran Sebagai Upaya Pembentukan Karakter Bangsa: Pkn Progresif, 12 (1) : 528-542.

Anita, L. (2002). Cooperative Learning . Jakarta : Gramedia Widiasarana. 
Direktorat Jenderal Kesatuan Bangsa dan Politik Departemen dalam Negeri. (2007. Peraturan Menteri Dalam Negeri Nomor 39 Tahun 2007 tentang pedoman Fasilitasi Organisasi Kemasyarakatan Bidang Kebudayaan, dan lembaga adat dalam pelestarian dan pengembangan budaya daerah.

Hand. N. (2006). Exploring sociocultural perspectives on race, culture, and learning: Review of Educational Research, 449-475.

Kemendikbud. 2014. Peraturan Menteri Pendidikan dan Kebudayaan Republik Indonesia Nomor 160 Tahun 2014 tentang Pemberlakuan Kurikulum Tahun 2006 dan Kurikulum 2013. Sekretariat Kemendikbud. Jakarta. Kurikulum Tahun 2006 dan Kurikulum 2013 pada Sekolah Jenjang Pendidikan Dasar dan Pendidikan Menengah. Kemendikbud. Jakarta.

Kusnadi. (2006). Filosofi Pemberdayaan Masyarakat Pesisir. Bandung : Humaniora

Nurhasanah. A. (2016). Pengembangan Materi ajar nilai-nilai budaya lokal (Studi Etnografi pada masyarakat adat Baduy): Candrasangkala. Vol $2(2): 62-70$.

Nadlir. (2014). Urgensi Pembelajaran Berbasis Kearifan Lokal: Pendidikan Agama Islam, 2(2): 299-330.

Perianto. E. (2018). Kearifan Lokal Sekolah Sebagai Basis Pengembangan Program Bimbingan Dan Konseling Komprehensif: Konseling Andi Matappa. Vol 2 (1) : 11-18. 
Mudarrisa: Jurnal Kajian Pendidikan Islam, Vol. 11, No. 1, 2019

Panggabean. H. (2014). Kearifan Lokal Keunggulan Global. Jakarta: PT. Gramedia.

Padmanugraha. (2010). Bentuk-bentuk Kearifan Lokal. Jakarta : Gramedia.

Rianawati. (2014). Implementasi Nilai-nilai Karakter Pada Mata Pelajaran Pendidikan Agama Islam. Pontianak: IAIN Pontianak Press.

Subagyo. (2012). Pengembangan nilai dan tradisi gotong royong dalam bingkai konservasi nilai budaya: Indonesian Journal of Conservation: Vol 1 (1) : 61-68.

Salamun. (2002). Budaya Masyarakat Suku Bangsa Jawa di Kabupaten Wonosobo. Tesis

Susanto. H. (2017). Pendidikan Berbasis Kearifan Lokal. Jakarta : PT. Remaja Rosdakarya.

Sunarto. (2008). Perkembangan peserta didik. Jakarta : PT. Renika Cipta.

Sartini. (2004). Menggali Kearifan Lokal Nusantara. Bandung : Alfabeta.

Sugiyono. (2017). Metodologi Penelitian Kualitatif. Bandung : Alfabeta.

Tilaar. (2002). Pendidikan, kebudayaan, dan masyarakat madani. Bandung : Remaja Rosdakarya.

Wahab. (2015). Sapa And Base Communication Of Sambas Society: A Case Of Malay-Madurese Post-Conflict 1999-2014: Of Scientific And Technology Research, 4(2), 253-256.

Zulkifli. (2017). Profesionalisme guru dalam mengembangkan Materi Ajar: Ilmiah, 3(2), 120-133. 